\title{
Vegetation and climate around 780 kyrs BP in northern Kathmandu valley, central Nepal
}

\author{
*Sima Humagain and Khum N. Paudayal
}

Central Department of Geology, Tribhuvan University, Kirtipur, Kathmandu, Nepal

\begin{abstract}
Palynological study from the Dharmasthali Formation exposed in the northern part of Kathmandu valley revealed the composition of forest vegetation that were growing in middle Pleistocene (780 kyrs BP) in this area. In a total fifteen samples were collected from the $46 \mathrm{~m}$ exposed section for the palynological study. The profile can be divided into two zones on the basis of pollen assemblages. The lower part (DF-I) is dominated by Pteridophyte spores such as Lygodium, Polypodium, Cyathea and Pteris. The dominance of Pteridophytes indicate that the forest floor was moist and humid. The tree pollen consists of Abies, Pinus, Quercus, Podocarpus and Alnus. Other Gymnosperms such as Picea and Tsuga were represented by very low percentage. Poaceae and Cyperaceae show their strong presence indicating grassland and wetland conditions around the depositional basin. In the upper zone (DF-II) there is increase of Gymnosperms such as Picea and Abies. The subtropical Gymnosperm Podocarpus decreased while Tsuga completely became absent in this zone. Cold climate preferring trees such as Cedrus, Betula, Juglans and Ulmus appeared first time in this zone. The climate became even colder and drier in the upper part of the section. Near water plants such as Cyperaceae and Typha show their dominance in this zone. The plant assemblages from bottom part of the Dharmasthali Formation indicate warm climate condition which was becoming colder after 780 kyrs towards the top part of the sequence.
\end{abstract}

Key words: Vegetation, climate, Kathmandu, Middle Pleistocene

Accepted: 27 June 2018

\section{INTRODUCTION}

The fluvial to fluvio-lacustrine sediments in the Kathmandu Basins are best archive to study the past vegetation and climate during the upliftment of the Himalaya. The plant microfossil and other plant remains obtained from the basin sediments have been studied by different researchers (Karl and Havinga 1979; Yoshida and Igarashi 1984; Mittre and Sharma 1984; Igarashi et al. 1988; Nakagawa et al. 1996; Ooi 2001; Fuji and Sakai 2001, 2002; Paudayal and Ferguson 2004; Paudayal 2005, 2006, 2011a, 2011b; Bhandari and Paudayal 2007; Bhandari et al. 2009, 2010, 2011a, 2011b, 2016; Khatri 2015). The Dharmasthali Formation is exposed in the northern part of the Kathmandu Basin. The palaeomagnetic age of the basal part of this formation is estimated as $>780 \mathrm{kyrs}$ BP (Gautam et al. 2001). In this paper we present the plant microfossils obtained from Dharmasthali Formation and explain their climatic significance.

\section{GEOLOGICAL SETTING}

The Kathmandu Basin developed within the Lesser Himalaya, filled with fluvio-lacustrine, fluvial and fluvio-deltaic sediments of Plio-Pleistocene to Holocene age (Yoshida and Igarashi 1984). The basin is considered to have been resulted from damming in the southern part of the valley and host more than $600 \mathrm{~m}$ thick unconsolidated to semi-consolidated clastic

*Corresponding author

Email: sima.humagain@gmail.com (S. Humagain) sediments of Plio-Pleistocene age (Moribayashi and Maruo 1980; Fuji and Sakai 2002). The valley sediments have been divided into seven stratigraphic units on the basis of lithology, facies analysis, radiocarbon dating and paleomagnetic polarity data (Yoshida and Igarashi 1984; Yoshida and Gautam 1988; Sakai et al. 2001; Sakai et al. 2008). The Lukundol Formation is an older formation and was deposited throughout the basin (Dhoundial 1966). Due to the activation of Main Boundary Thrust (MBT), the Mahabharat range in the south started rising which caused the basin tilted northward leading subsequently to the formation of three terraces (the Pyangaon, Chapagaon, and Boregaon Terrace Deposits) in the south. Further activation of Main Boundary Thrust created a new favorable environment for deposition of younger sediments of the Gokarna, Thimi, and Patan formations in the northern part of the valley (Yoshida and Igarashi 1984; Igarashi et al. 1988). On the basis of detail lithological and facies analysis, radiocarbon dating and previously reported paleomagnetic polarity data, Sakai et al. (2008) revised the basin deposits and divided them into the Dharmasthali, Kalimati, Gokarna, Thimi, Tokha, and Patan formations respectively in ascending order. The Dharmasthali Formation can be correlated with the Lukundol Formation mostly exposed to the southern part of the Kathmandu valley (equivalent to Pliocene to lower Pleistocene succession). The Dharmasthali Formation is deposited underlying Sheopuri Gneiss as basement rock (Fig. 1). It mainly consists of gravelly sand, conglomerate, clastic clay, poorly sorted gravel at the bottom part (Fig. 2 and 3a). The gravel and conglomerate consists of pebble to boulder size 


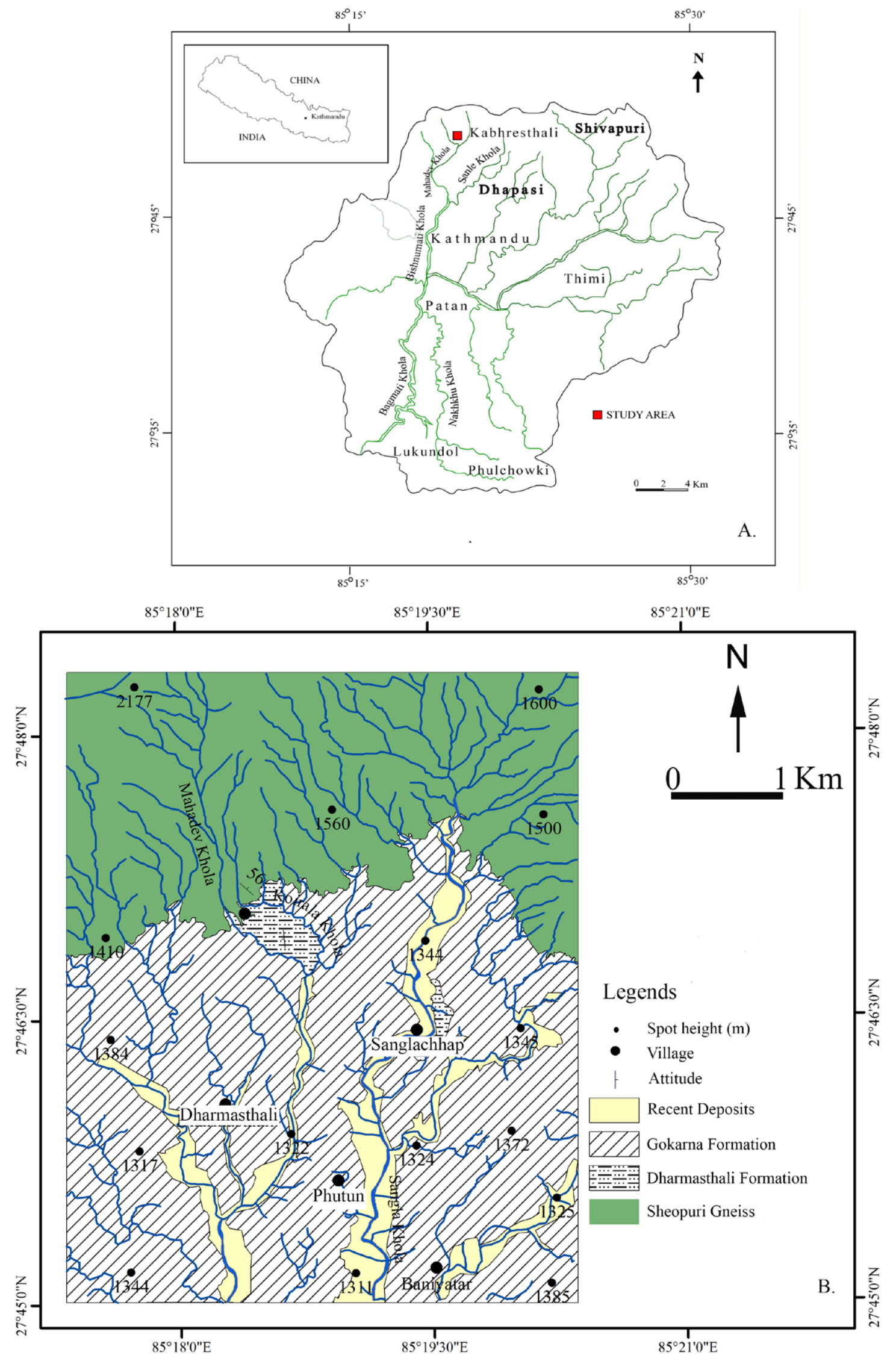

Fig. 1: (A). Location of the study area, (B). Geological map of the northern part of the Kathmandu Basin. The horizontal dashed lines indicate the distribution of the Dharmasthali Formation along the Mahadev Khola, Koirala Khola and Sangla Khola. 
gravel, rounded to sub rounded in nature. The gravel bed is clast dominated at the bottom part and sand dominated at its top part. The massive or inversely graded gravel and sand beds have been deposited by gravity flow such as debris flows or small-scale grain flows (Nemec 1990). The middle part (Fig. $3 \mathrm{~b}$ ) consists of alternating layers of gravelly sand, silt and silty clay. The gravelly sand (Fig. 3d) are composed of clasts of metasandstone and gneiss upto clast size $4 \mathrm{~cm}$. Its top part (Fig. 3c) consists of gravelly sand, clay, silty clay, sand and lignite layers. The lignite layer is measured upto $80 \mathrm{~cm}$ and consists of plant debris with needles of different gymnosperms. In gravelly sand and sand layers cross beddings which are the indicator of paleo-flow direction were observed (Fig. 3e). The iron concretion (Fig. 3f) was observed in clay layers which indicates several stages of partial exposure of the Dharmasthali Formation to atmosphere during deposition. The Dharmasthali Formation is exposed near the confluence of Mahadev Khola and Koirala Khola at the vicinity of Kabhresthali. Altogether fifteen samples were taken from $46 \mathrm{~m}$ thick surface exposure from clay, silty clay, silt and lignite layers for the palynological study.

\section{MATERIAL AND METHODS}

Fifteen samples collected for palynological study were prepared at the laboratory of Paleobotany and Palynology at the Central Department of Geology, Tribhuvan University, Kirtipur, Kathmandu following the method described by Ferguson et al. (2007). Firstly, the samples were treated with conc. Hydrochloric acid to remove carbonates and subjected to Hydrofluoric acid to remove silicates. They are then treated with conc. Hydrochloric acid to remove fluorite. Acetolysis was done by treating the samples with acetolysis solution $(9: 1$ ratio of acetic anhydride and conc. $\mathrm{H}_{2} \mathrm{SO}_{4}$ ). The samples were washed with glacial acetic acid and water after every treatment. Finally, the samples were centrifuged in heavy liquid $\left(\mathrm{ZnCl}_{2}\right)$ with sp. gravity 2.0 in order to extract organic matter from inorganic remains. The extracted organic matter was studied under OLYMPUS-BX43 light microscope for the identification and counting of pollen and spore. At least 300 pollen grains were point counted from rich and 200 pollen from poor samples and the percentage of individual taxa was calculated from the pollen sums. OLYMPUS-DP73 camera with cellSens Entry software was used to take the photograph of the palynomorph. The data was represented in the form of pollen diagram using software TILIA. Graphical software ArcGIS, CorelDRAW, Photoshop and Macromedia FreeHand MXa were used to prepare the figures. The pollen and spores counted from each samples were identified at least to generic level and some up to family level. Previously published atlas and several literatures were consulted to identify the palynomorphs (Krutzsch 1963; Academia Sinica 1982; Gupta and Sharma 1986; Malla et al. 1986; Punt et al. 1994; Tissot et al. 1994; Fuhsiung et al. 1995; Beug 2004; Hesse et al. 2009).

\section{RESULTS}

Altogether 94 species of plants belonging to 30 families

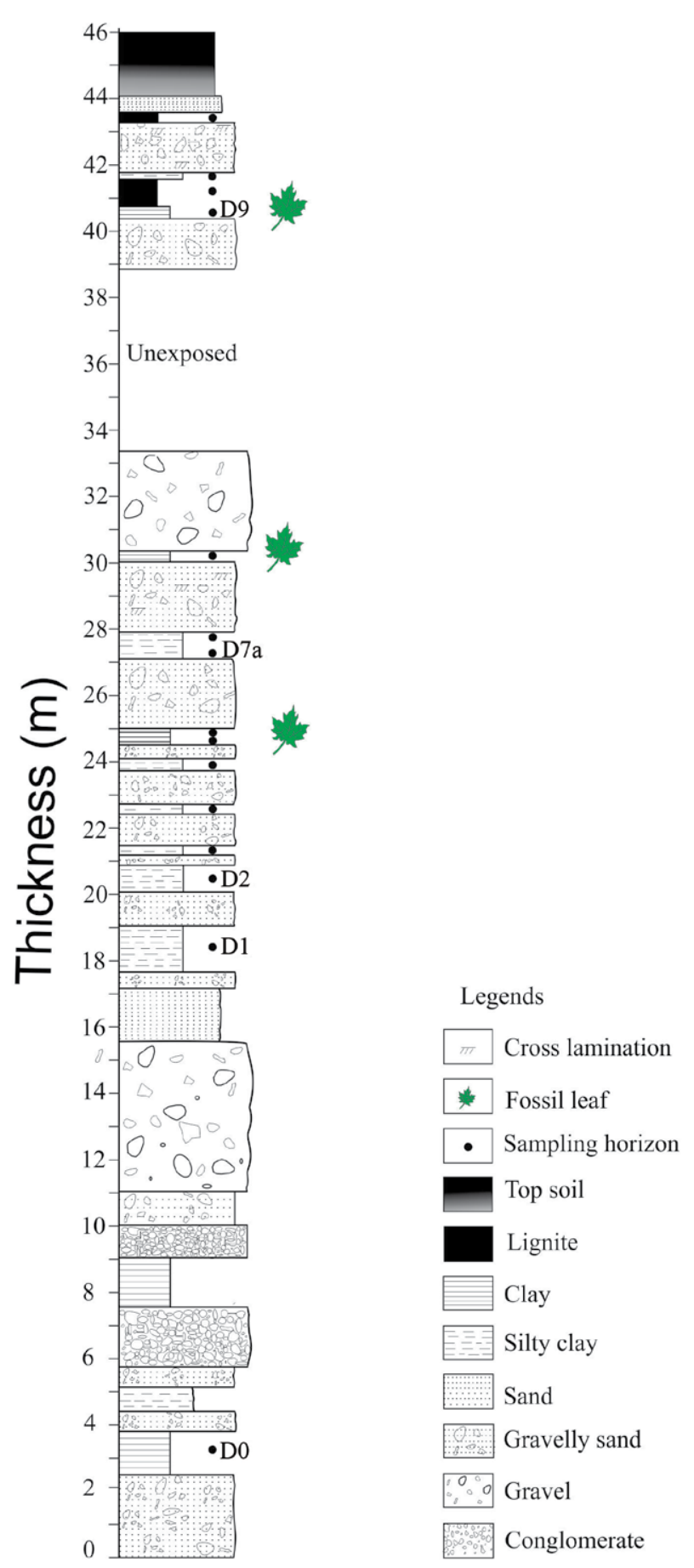

Fig. 2: Lithological details of the Dharmasthali Formation with sampling horizons.

were recorded from the samples collected from the different horizon of Dharmasthali Formation. Gymnosperm consists of 6 species belonging to 2 families. Angiosperm consists of both Dicotyledon and Monocotyledons. The Dicotyledon consists of 16 families with 40 species and monocotyledon consists of 4 families with 11 species. Pteridophytes consist of 7 families with at least 33 species. The details of the plant taxa obtained from the Dharmasthali Formation are listed in Table 1. The photographs of all pollen and spores are presented in Plates I-V. 

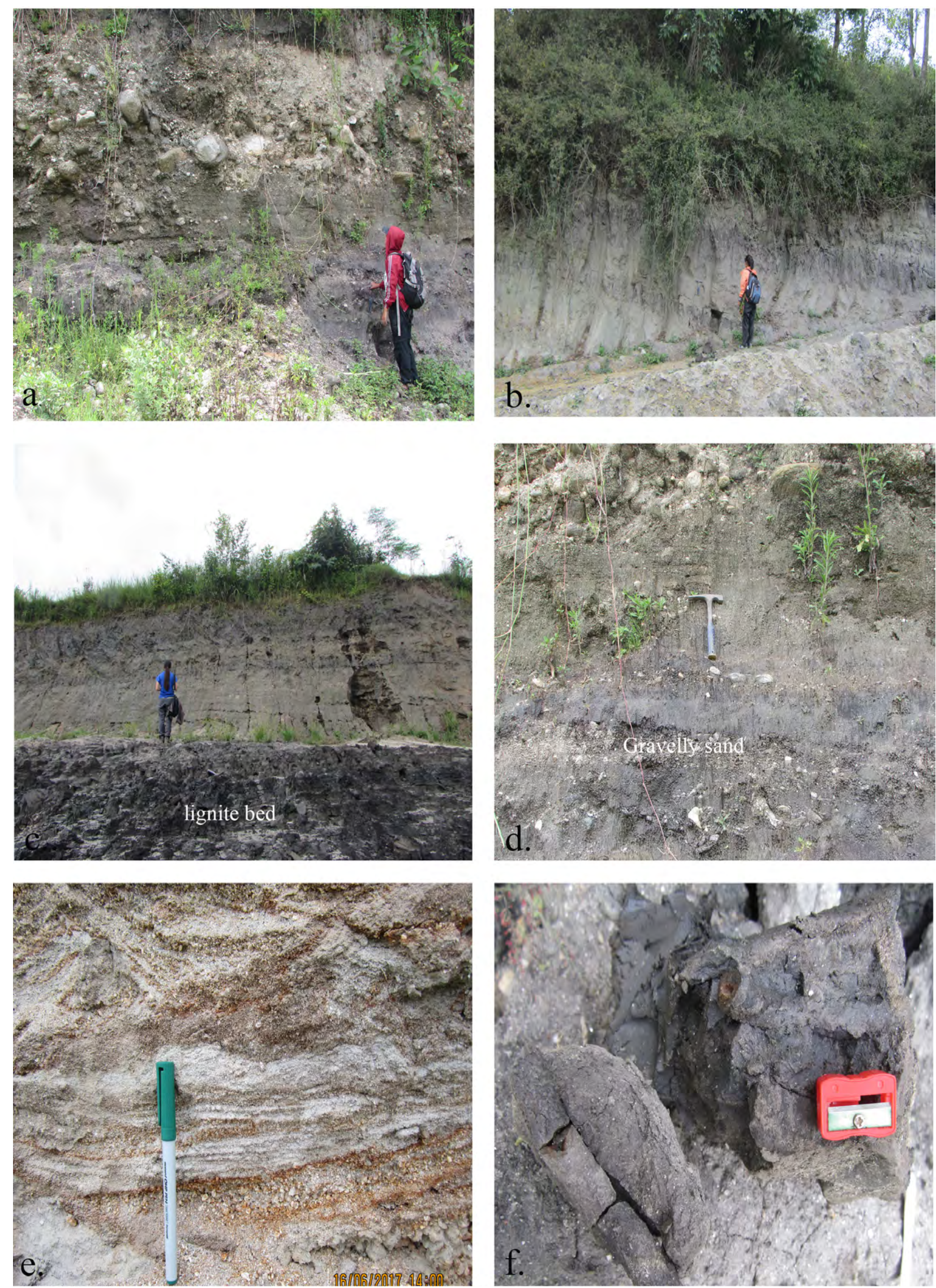

Fig. 3: (a). Basal part of the Dharmasthali Formation consisting gravel and conglomerate beds, (b). Middle part of the Dharmasthali Formation, (c). Top part of the Dharmasthali Formation consisting lignite bed, (d). Gravelly sand beds, (e). Cross beddings in sand layer, (f). Iron concretion in clay bed. 
Table 1: List of plant taxa recovered from the Dharmasthali Formation.

\begin{tabular}{|c|c|c|c|c|}
\hline Division & & Family & Species & No. of Species \\
\hline & & & Abies sp. & 1 \\
\hline & & & Cedrus sp. & 1 \\
\hline Gymnosnerm & & Pinaceae & Picea sp. & 1 \\
\hline Cymosperim & & & Pinus sp. & 1 \\
\hline & & & Tsuga sp. & 1 \\
\hline & & Podocarpaceae & Podocarpus sp. & 1 \\
\hline & & A conthoceoe & Justicia $\mathrm{sp}$. & 1 \\
\hline & & Acantnaceae & Strobilanthes sp. & 3 \\
\hline & & Apiaceae & Apiaceae gen. indet. & 4 \\
\hline & & Araliaceae & Araliaceae gen. indet. & 2 \\
\hline & & & Alnus sp. & 1 \\
\hline & & Betulaceae & Betula sp. & 1 \\
\hline & & & Colylus sp. & 1 \\
\hline & & Caryophyllaceae & Caryophyllaceae gen. indet. & 1 \\
\hline & & Chenopodiaceae & Chenopodiaceae gen. indet. & 1 \\
\hline & & Comnocitae & Artemisia sp. & 2 \\
\hline & Dicotvledon & Compositac & Compositae gen. indet. & 8 \\
\hline & Dreogicasie & Dipsacaceae & Dipsacus sp. & 1 \\
\hline Angiosnarm & & Elaeagnaceae & Elaeagnus sp. & 1 \\
\hline Aingoupserim & & Euphorbiaceae & Euphorbiaceae gen..indet. & 1 \\
\hline & & Fagaceae & Quercus sp. & 6 \\
\hline & & Juglandaceae & Juglans sp. & 1 \\
\hline & & Oleaceae & Jasminum sp. & 1 \\
\hline & & Polygalaceae & Polygalaceae gen. indet. & 1 \\
\hline & & Polvornonere & Fagopyrum sp. & 1 \\
\hline & & Porygonacede & Polygonum sp. & 1 \\
\hline & & Ulmaceae & Ulmus sp. & 2 \\
\hline & & Urticaceae & Urtica sp. & 1 \\
\hline & & Cyperaceae & Cyperaceae gen. indet. & 3 \\
\hline & Monotvllodn & Liliaceae & Liliaceae gen. indet. & 4 \\
\hline & Honocotyction & Poaceae & Poaceae gen. indet. & 1 \\
\hline & & Typhaceae & Typha sp. & 3 \\
\hline & & Cyatheaceae & Cyathea sp. & 4 \\
\hline & & Davalliaceae & Davallia sp. & 3 \\
\hline & & Lycopodiaceae & Lycopodium sp. & 1 \\
\hline & & Lygodiaceae & Lygodium sp. & 4 \\
\hline Pteridophyta & & Polynodiacene & Arthomeris sp. & 2 \\
\hline & & Toryponiac eac & Polypodiaceae gen. indet. & 13 \\
\hline & & Dtoridoogon & Acrustichum sp. & 1 \\
\hline & & Pterraceae & Pteris & 5 \\
\hline & & Selaginellaceae & Selaginella sp. & 2 \\
\hline
\end{tabular}




\section{Pollen assemblages and pollen zones}

On the basis of available pollen taxa a pollen diagram was prepared to find the change in vegetation with respect to time. The percentage of each taxa was plotted in $\mathrm{x}$-axis while $\mathrm{y}$-axis indicate the stratigraphical position of the samples. The pollen diagram of the Dharmasthali Formation can be divided into two zones, i.e. DF-I and DF-II (Fig. 4). The palynological assemblage of each zone is described below.

\section{Pollen assemblage zone DF-I}

The DF-I zone consists of dominance of Pteridophyte spores. The spore of Lygodium (30-60\%) and Polypodiaceae (5-35\%) are distributed throughout the zone. Pteridaceae and other trilete spore are represented by $(2-30 \%)$. The Gymnosperm pollen Pinus (2-10\%) and Picea sp. (1-3\%) shows low frequency in this zone. Podocarpus and Tsuga sp. are less than $2 \%$ whereas Abies is distributed less than 1\%. Cedrus sp. is totally absent in this zone. The tree species Quercus (1-11\%) shows low frequency. The herbs like Caryophyllaceae 1\%, Artemisia (1-3\%) shows their appearance at very lower vlaue whereas Poaceae (2-10\%) and Compositae (1-15\%) shows a little higher frequency than other herbs. The wetland plant Cyperaceae (5-20\%) also shows high percentage along with other. Algal and Fungal spore constitute (5-15\%) in the zone.

\section{Pollen assemblage zone DF-II}

The DF-II zone shows significance decrease in Pteridophytes spore and increase in coniferous trees along with angiosperm trees and herbs. Lygodium sp. (3\%-30\%), Polypodiaceae (2$35 \%$ ) was decreased in their frequencies except in some areas. The Pinus sp. (2-9\%) shows almost equal frequency as in the first zone. Abies sp. increased in this zone whereas Picea and Podocarpus sp. also show their similar frequencies as in the first zone. The most distinguishing feature of this zone is the appearance of Cedrus sp. and Ulmus sp. by up to $1 \%$, which were totally absent in the previous zone. Tsuga sp. became absent in this zone. There is significant increase of Quercus (5$40 \%$ ) in this zone. The broad leaved trees like Betula, Alnus, Juglans shows their appearance in this zone. In DF-I there was no Juglans pollen. The occurrence of temperate element such as Juglas indicates there was significant change in climate at this time. The herbs like Dipsacus, Strobilanthes, Urtica,

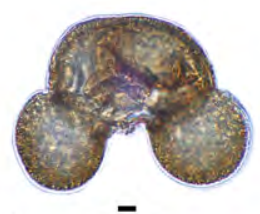

1.



4

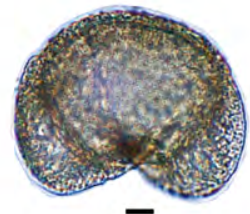

2.

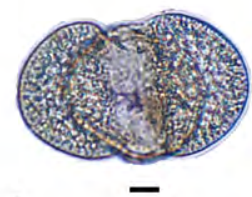

5.

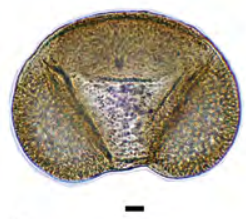

3.

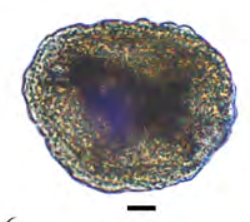

6.
Caryophyllaceae, Araliaceae, and Apiaceae are less than 1\%. These plants were totally absent in DF-I. Chenopodiaceae constitutes 2\% and Artemisia (1-1.5\%) is declined in this zone. Compositae shows slightly increased frequency (1-15\%). The wetland plants such as Typha (1-4\%) appeared in this zone whereas Cyperaceae (10-70\%) shows very high percentage. Cyperaceae were signicantly present in DF-I but they became more prominent in DF-II pollen zone. Liliaceae attain their value upto $1-3 \%$ in DF-II. Liliaceae were absent in DF-I. Algal spore shows similar frequency as that of DF-I.

\section{DISCUSSION AND CONCLUSION}

The pollen and spores recorded from the Dharmasthali Formation indicate the plant biome grown in that area during or after 780 kyrs. Plants are very sensitive to their surroundings and they grow according to their suitable climate. It is supposed that the climatic requirement of the plants in the past that were growing in a particular area had same climatic parameters that are required for their Nearest Living Relatives (NLRs) growing today (Mosbrugger and Utescher 1997). The coniferous trees are mostly grown in cold climate. The gymnosperms such as Abies (2400-4400 m), Picea (2300-3600 $\mathrm{m})$, Tsuga (2100-3600 m), and Cedrus (2000-4000 m) grow in temperate forest while Podocarpus (1000-1100 m) grow in subtropical areas in Nepal (Press et al. 2000). Pinus are found in subtropical to temperate climate at an altitude of 1100-4100 $\mathrm{m}$ (Press et al. 2000). The broad leaf trees like Betula (1200$4300 \mathrm{~m}$ ) and Juglans are grown in cold temperature. Quercus species are mostly found in sub-tropical to temperate climate. Different species of Quercus are found from altitude of 450 to $3800 \mathrm{~m}$ in Nepal (Press et al. 2000). Quercus semecarpifolia are found from 1700 to $3800 \mathrm{~m}$, Quercus glauca are found from 450 to $3100 \mathrm{~m}$ while Quercus lanata occur from 460 to $2600 \mathrm{~m}$ (Malla et al. 1976; 1986). Identification of Quercus pollen upto species level could provide strong evidence of climate from past but identification of Quercus upto this level is only possible by using SEM (Paudayal and Ferguson 2004; Ferguson et al. 2007). Alnus (500-2600 m) grow in wet and moist areas along river valleys. Corylus is distributed from 1900 to $3200 \mathrm{~m}$ in temperate forest while Ilex is common tree in tropical-subtropical forest. Typha and Polygonum indicate the near water and wetland conditions. The plants like Araliaceae and Apiaceae are distributed in the subtropical to temperate region mostly in shady places. The occurrence of Araliaceae probably indicates the influence of windblown upland flora (Rao et al. 2013). Dipsacus usually occurs in moist and shady place whereas Compositae also occur in moist and shady place excluding Artemisia occurring in open place. Polygalaceae are found in dry Schima forest at 1300-3600 m altitude growing in sunny places. Chenopodiaceae, a weedy herb and Euphorbiaceae occur in secondary forest (GoN 2009). The pteridophytes spores like Lycopodium, Lygodium, Selaginella occur in shady area and are found in tropical to temperate forest regions. The Pteris sp. shows mostly tropical and sub- tropical climate occurring in shady moist and open dry place. Cyathea are typically terrestrial, occurring on warm humid places and along the stream side at (1300-2000 $\mathrm{m})$ altitude. They are distributed in tropical, sub-tropical and temperate forest. The Davalliaceae is found in mossy tree

5. Podocarpus, and 6. Tsuga (Scale bar $=10 \mu \mathrm{m})$. 
Vegetation and climate around 780 kyrs BP in northern Kathmandu valley, central Nepal

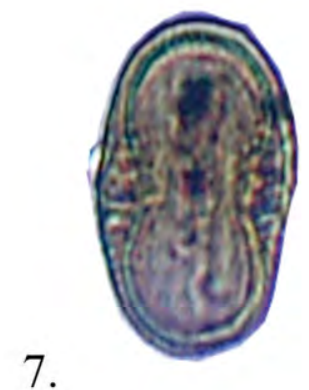

7.



11.

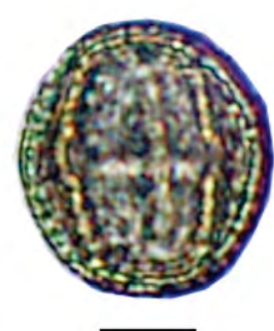

15.

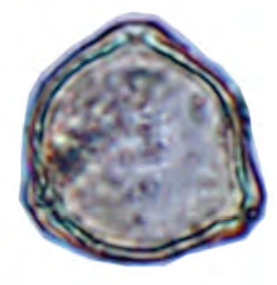

19.

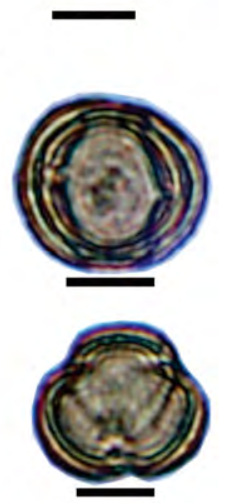

8.
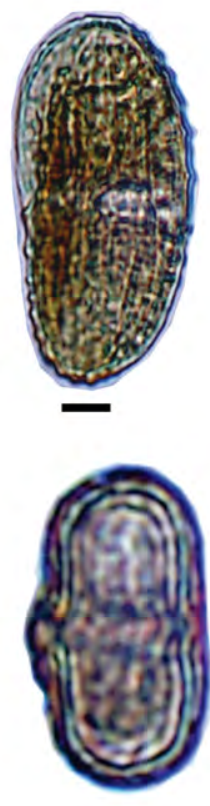

12.

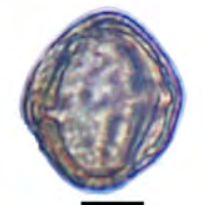

16.
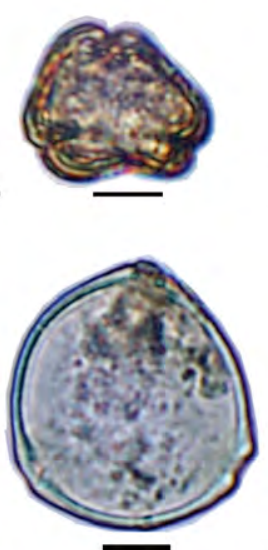

20.
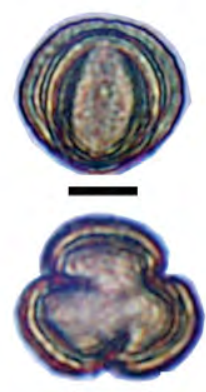

24.
9.

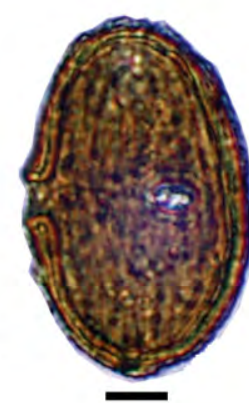

10.

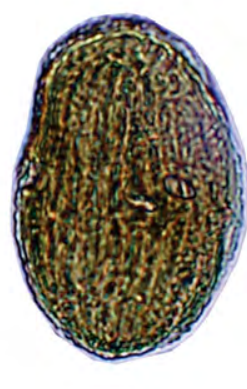

13.

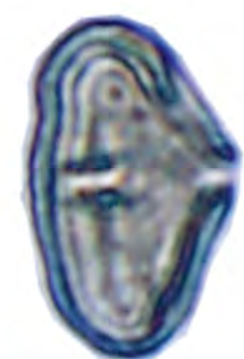

14.

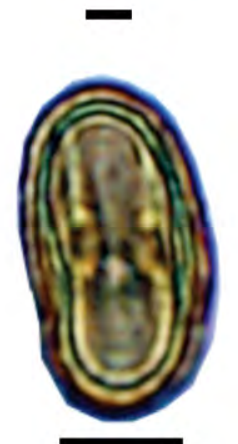

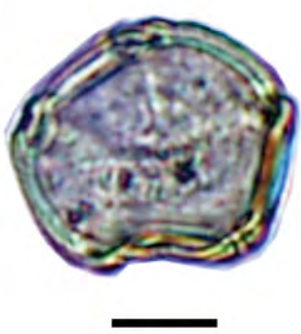

17.

18.

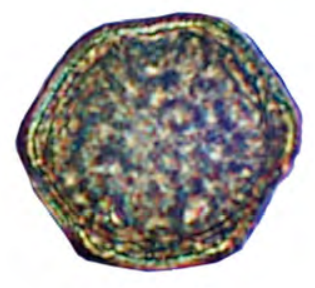

21.

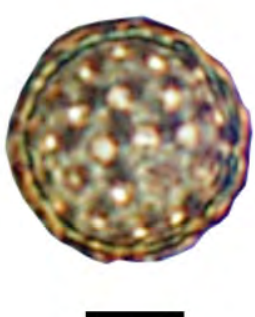

22.

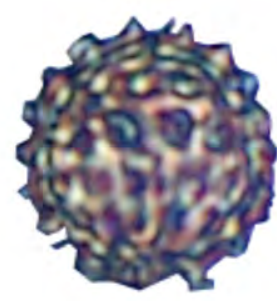

25.

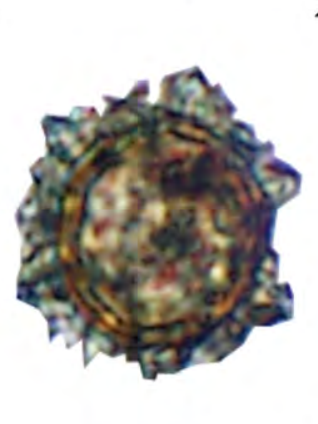

26.

Plate II: 7. Justicia, 8-10. Strobilanthes, 11-14. Apiaceae, 15-16. Araliaceae, 17. Ilex, 18. Alnus, 19. Betula, 20. Corylus, 21. Caryophyllaceae, 22. Chenopodiaceae, 23-24. Artemisia, 25-26. Compositae (Scale bar $=10 \mu \mathrm{m})$. 


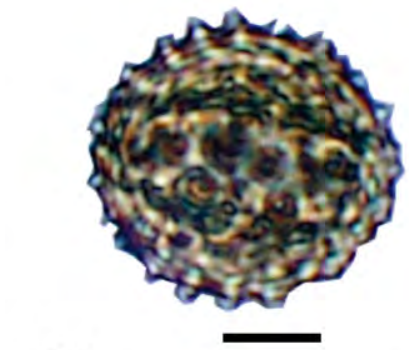

27.



31.



35.

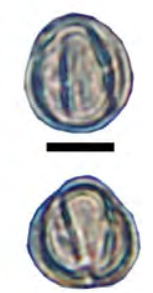

39.

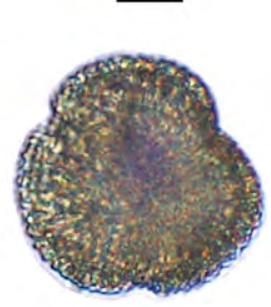

43.

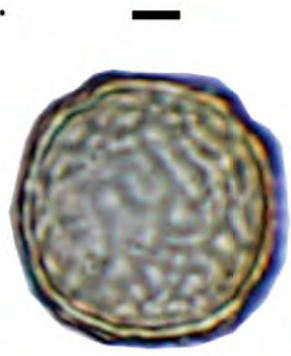

47.



28.

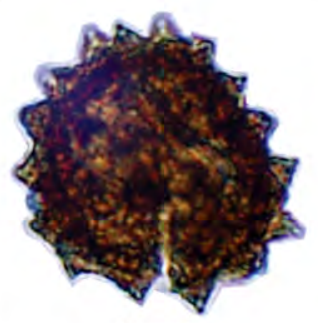

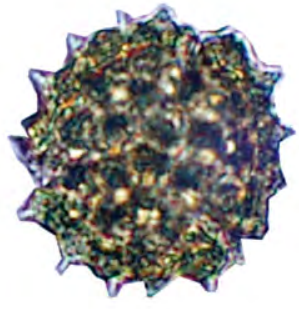

29.

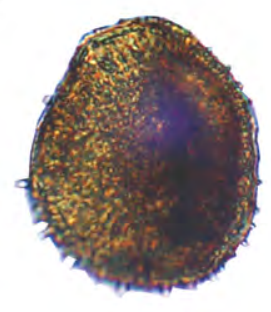

33.
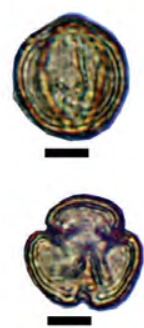

36.

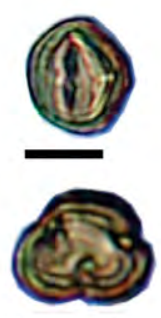

40.

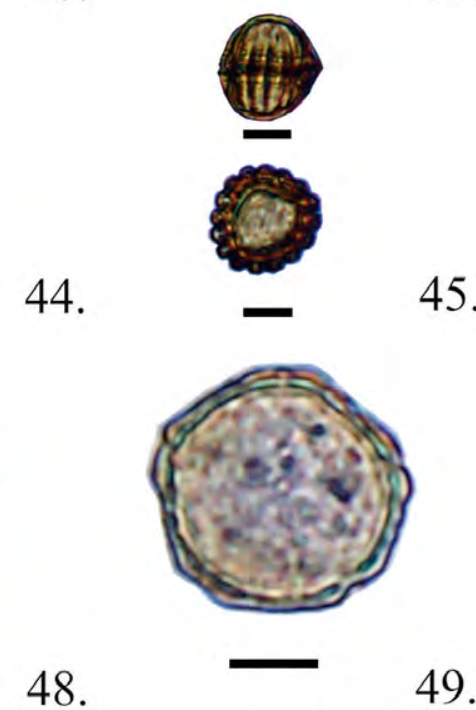

44.

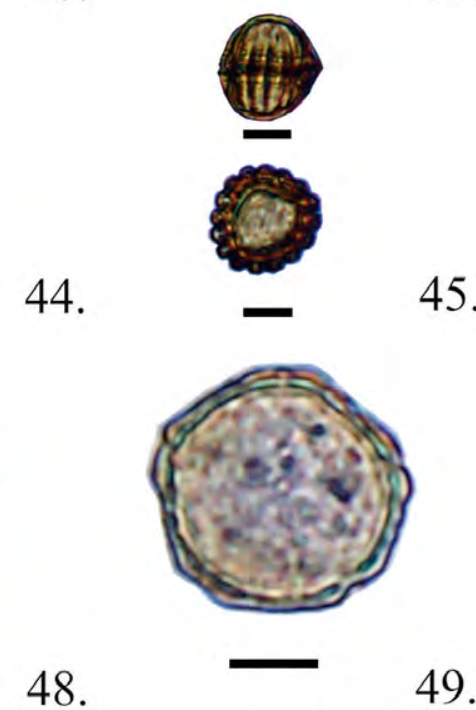

48.

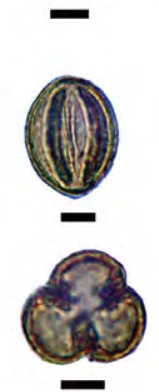

37.

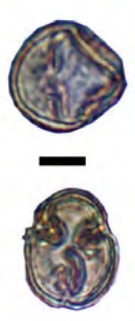

41.
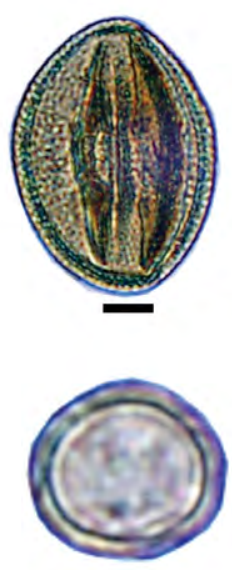

34.



30.



38.
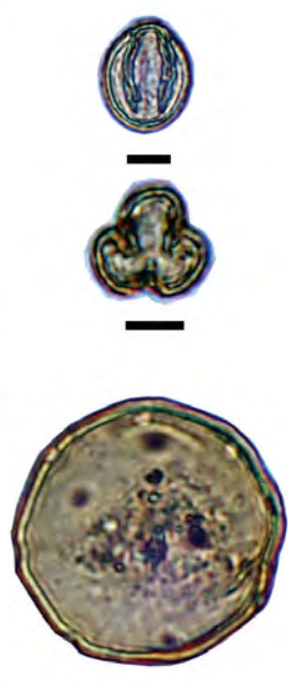

42.

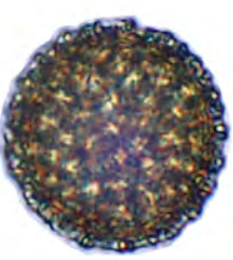

46.

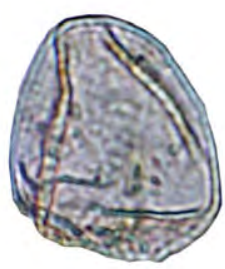

50.

Plate III: 27-32. Compositae, 33. Dipsacus, 34. Eleagnus, 35. Euphorbiaceae, 36-41. Quercus, 42. Juglans, 43. Jasminum, 44. Polygalaceae, 45. Fagopyrum, 46. Polygonum, 47-48. Ulmus, 49. Urtica, 50. Cyperaceae (Scale bar $=10 \mu \mathrm{m})$. 
Vegetation and climate around 780 kyrs BP in northern Kathmandu valley, central Nepal
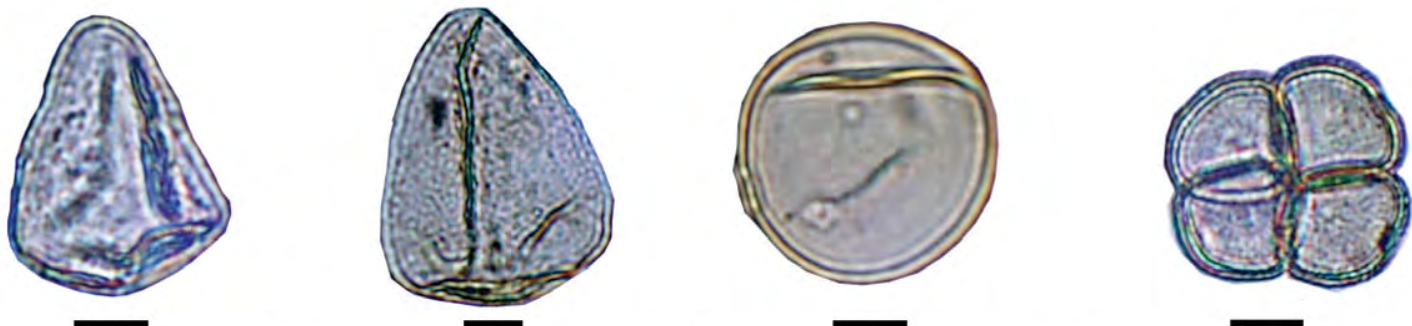

51.

52.

53.


55.

56.

57.
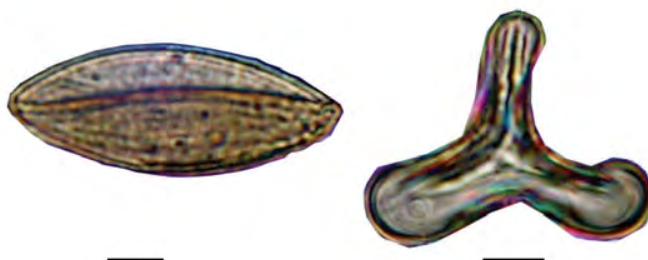

58.

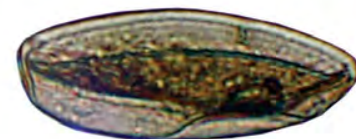

60.

61.

62.
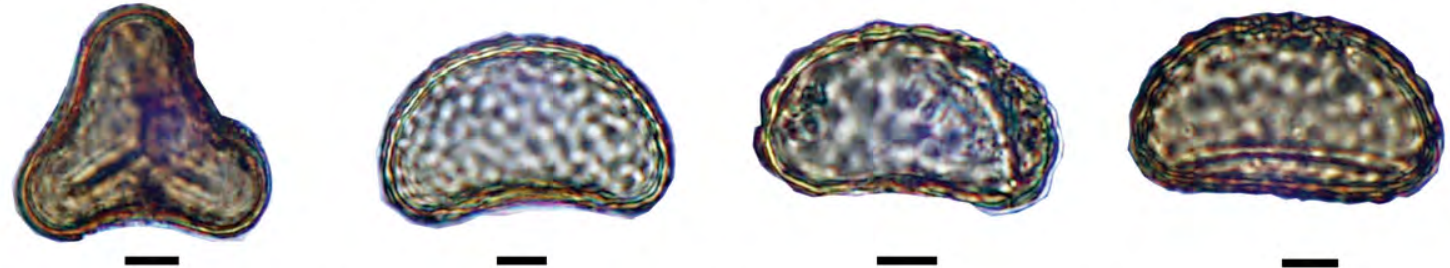

63.

64.

65.
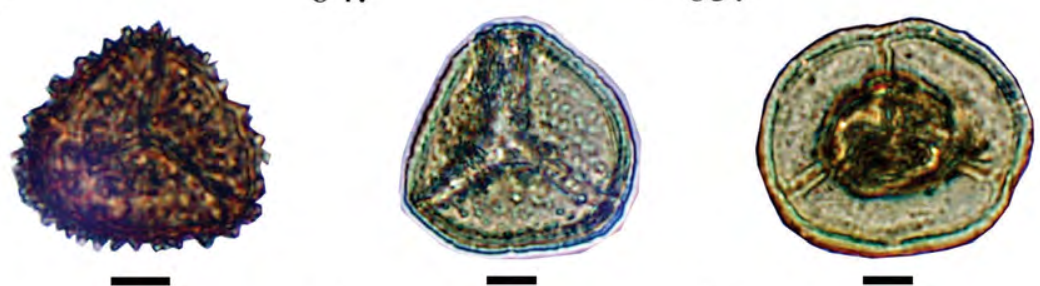

66.

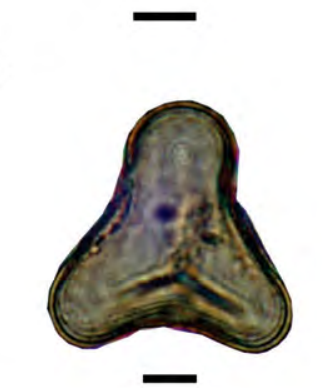

54.

67.

68.

69.

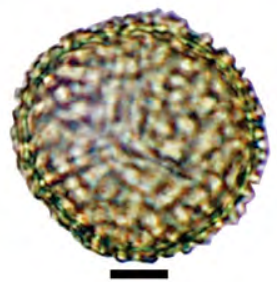

71.
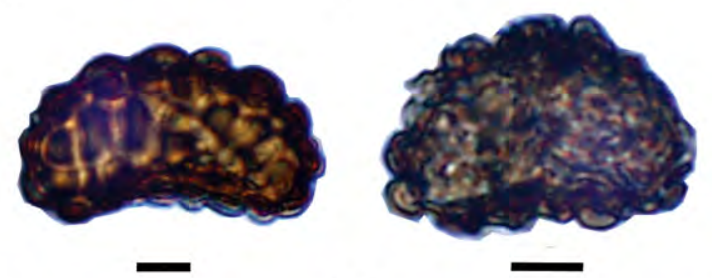

73.

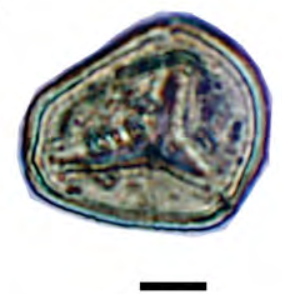

70.

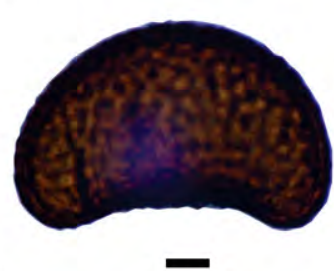

72.

74.

Plate IV: 51-52. Cyperaceae, 53. Poaceae, 54-56. Typha, 57-60. Liliaceae, 61-63. Cyathea, 64-66. Davallia, 67. Lycopodium, 6871. Lygodium, 72-73. Arthomeris, 74. Polypodium (Scale bar $=10 \mu \mathrm{m})$. 


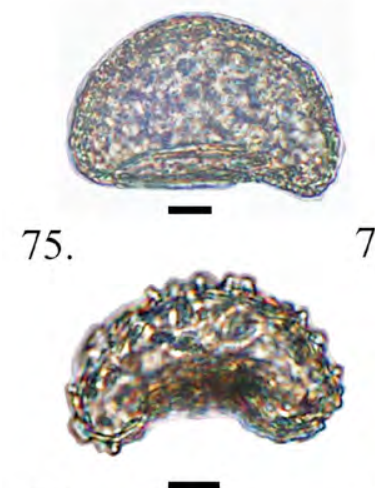

79.

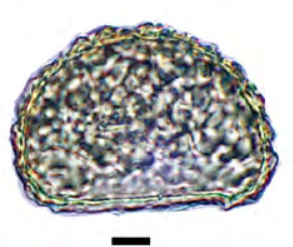

83.

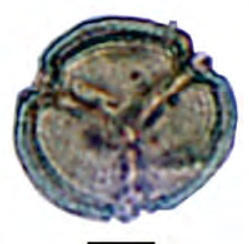

87.

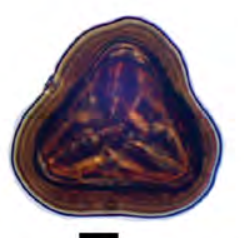

91.

92.

88.

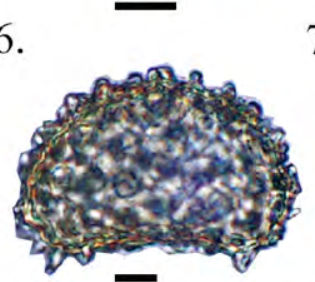

80.

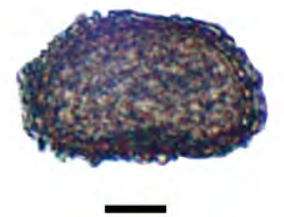

77.

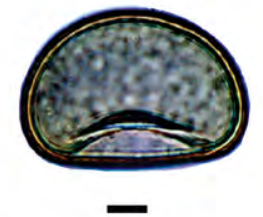

7.

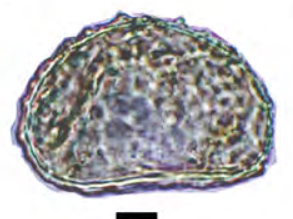

81.

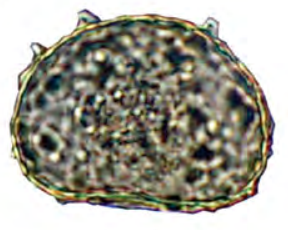

84.
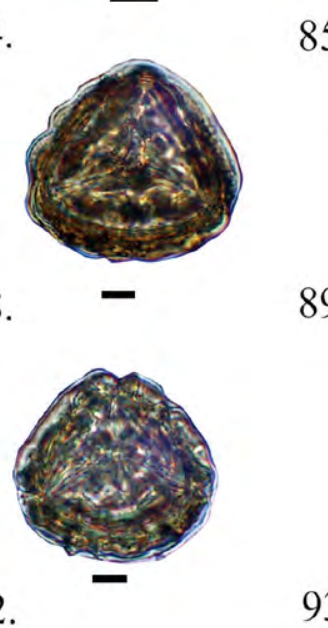

.

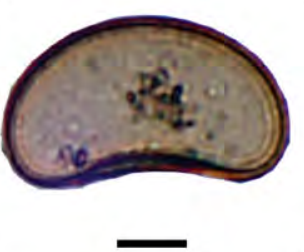

85.

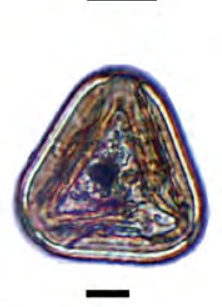

89.

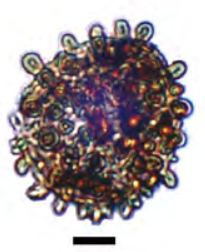

93.



78.

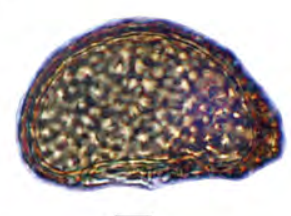

82.

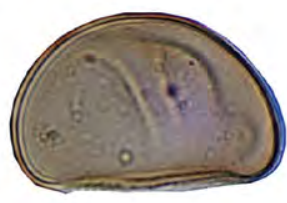

86.

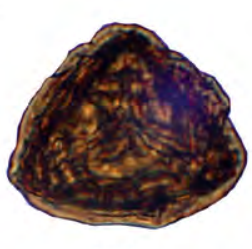

90.

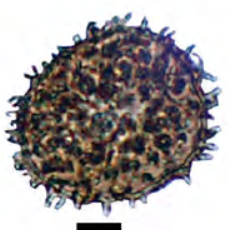

94.

Plate V: 75-86. Polypodiaceae 87. Acrustichum, 88-92. Pteris, 93-94. Selaginella $($ Scale bar $=10 \mu \mathrm{m})$.

trunks as well as on rocky slopes of shady and moist areas in temperate forest. The Polypodiaceae are frequently occurring on tree trunks and mossy rock, mostly on shady and moist parts of the tropical to temperate forest. The Arthomeris sp. is an epiphyte, grow on shady and wet places. Acrostichum (Pteridaceae) grows in swamps and other wet locations. The pollen zone DF-I is abundant in pteridophytes spores than angiosperm and gymnosperm pollen. Most of the pteridophytes grown in moist and shady places in tropical to temperate forest. The zone is abundant in Lygodium and Polypodiaceae species about $10 \%$ to more than $70 \%$ which indicates the warm shady and moist environment during the deposition of the DF-I zone. The Cyatheaceae, Lycopodiaceae and Pteridaceae are indicator of thick and tropical forest (Rao et al. 2013). The forest floor was covered by dense bushes in the first zone as fern spores indicate forest floor vegetation. Poaceae occupy $5-15 \%$ while fern species are upto 30\% in DF-I zone. Within the sub aerial facies relatively high number of fungal spores and Poaceae are assumed to reflect zonal herbaceous pioneer vegetation within the depositional environment (Paudayal 2006). The angiosperm trees like Quercus and Alnus shows very low frequency (5$20 \%$ ) followed by appearance of gymnosperm trees like Pinus and Podocarpus in low frequency. This also indicates the influence of warm and humid climate in the lower part of the Dharmasthali Formation around 780 kyrs. Comparing with stratigraphy this zone consists of gravelly sand, gravel, conglomerate along with silty clay and a layer of clay. Most of the samples from this zone were poor in palynomorphs. The gravel and conglomerate beds indicate influence of river in lacustrine environment. The fungal remains consist of fruiting bodies, hyphae, and spores indicating activity of saprophytic fungi which occur in deltaic sediments (Traverse 1988). In DF-II zone gymnosperm and angiosperm trees increased as compared to DF-I. High frequency of Abies, Picea, Tsuga, Cedrus and Pinus indicate the colder climatic condition in the upper part of this zone. Some angiosperm trees like Alnus, Betula, and Juglans are also key genera for cold and dry climate which were frequently found in this zone. Gymnosperm trees are dominant over angiosperm trees in DF-II indicating cold and dry climate during deposition of top part of the formation. 


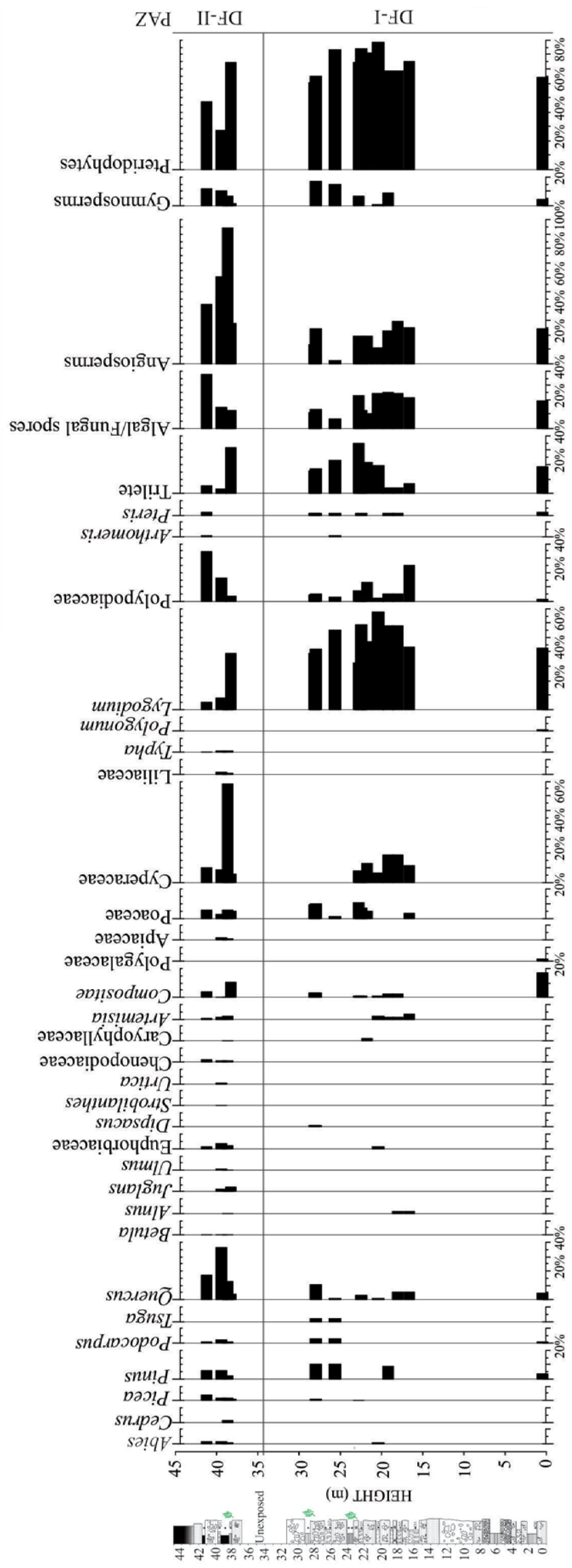

Fig. 4: Pollen diagram from the Dharmasthali Formation.
The appearance of Abies and Cedrus species in this zone highly suggest cold and dry climate. The Cedrus sp. is found at an altitude of 2000-4000 $\mathrm{m}$ in Nepal. They are found only in Dolpa and some other parts of western Nepal. In Kathmandu valley Cedrus and Ulmus species are not found in modern natural forest. The occurrence of these two plant species in the Dharmasthali Formation indicates that they were growing in Kathmandu around 780 kyrs. The Cedrus sp. was recorded by Igarashi et al. (1988) and the Ulmus sp. was recorded by Yoshida and Igarashi (1984) in the Lukundol Formation exposed in southern part of the Kathmandu Basin. The pteridophytes spore shows decreasing frequency in DF-II zone indicating shifting of moist environment to dry. The palynomorph record from different horizon from the Dharmasthali Formation suggests ununiform climate and diversity of vegetation during the deposition of sediments. High frequency of pteridophytes spore over angiosperm and gymnosperm trees in DF-I zone indicate warm, moist and humid climate at the basal part of Dharmasthali Formation. The increasing frequency of angiosperm and gymnosperm trees and decreasing frequency of fern spores indicate cold and dry climate at the top part of the formation. In the top part, layers of Lignite were found which are rich in plant debris mostly needles of Pinus, Picea etc. which also indicate cold climate at the time of deposition of top part. Lignite are mostly deposited in swampy environment where plant remains can be easily buried. The lignite bed was rich in Cyperaceae and Typha pollen which indicates swampy environment around Kathmandu Basin. The strong presence of cold and dry elements such as Cedrus, Abies, Ulmus, Betula, and Juglans also confirm that the cold and dry climate was prevailed during the deposition of DF-II zone.

\section{ACKNOWLEDGEMENTS}

The authors would like to thank Prof. Lalu Paudel, head of the Central Department of Geology, Tribhuvan University for providing necessary facility to carry our this research.

\section{REFERENCES}

Academia Sinica, 1982. Angiosperm pollen flora of tropic and subtropic of China. Academia Sinica, $453 \mathrm{p}$.

Beug, H.-J., 2004. Leitfaden der Pollenbestimmung für Mitteleuropa und angrenzende Gebiete. Verlag Dr. Friedrich Pfeil, München. $542 \mathrm{p}$.

Bhandari, S., and Paudayal, K.N., 2007. Palynostratigraphy and Palaeoclimatic interpretation of the Pliocene-Pleistocene Lukundol Formation from the Kathmandu valley, Nepal. Jour. Nepal Geol. Soc., v. 35, pp. 1-10.

Bhandari, S., Momohara, A., and Paudayal, K.N., 2009. Late Pleistocene plant macrofossils from the Gokarna Formation of the Kathmandu valley, central Nepal. Bull. Dept. Geol., Tribhuvan University, v. 12, pp. 75-88.

Bhandari, S., Paudayal, K.N., and Mamohara, A., 2010. Late Pleistocene plant macrofossils from the Thimi Formation (Madhyapur, Thimi section) of the Kathmandu valley, central Nepal. Jour. Nepal Geol. Soc., v. 40, pp. 31-48.

Bhandari, S., Paudayal, K.N., and Mamohara, A., 2011a. Climate change on the basis of plant macrofossil assemblages from the Late Quaternary sediments from the Mulpani section of the Gokarna Formation, Kathmandu valley, Nepal. Jour. Strat. Asso. Nepal, v. 7, pp. 47-58. 
Bhandari, S., Paudayal, K.N., and Mamohara, A., 2011b. Late Quaternary plant macrofossils assemblages from the Besigaon section of the Gokarna Formation, Kathmandu valley, central Nepal. Jour. Nepal Geol. Soc., v. 42, pp.1-12.

Bhandari, S., Momohara, A., Uhl, D., and Paudayal, K.N., 2016. Paleoclimatic significance of the Late Quaternary plant macrofossils from the Gokarna Formation, Kathmandu valley, Nepal. Rev. Palaobot. Palyno., pp. 98-112.

Dhoundial, E.P., 1966. Investigation of lignite deposits in Kathmandu valley, Nepal. Geol. Serv. of India report (Unpublished), 34 p.

Ferguson, D.K., Zetter, R., and Paudayal, K.N., 2007. The need for the SEM in Palaeopalynology. Comptes Rendus Palevol, 6 (67), pp. 423-430.

Fuhsiung, W., Nanfen, C., Yulong, Z., and Huiqiu, Y., 1995. Pollen flora of China. Academia Sinica, $461 \mathrm{p}$.

Fuji, R., and Sakai, H., 2001. Palynological study of the drilled sediments from the Kathmandu Basin and its palaeoclimatic and sedimentological significance. Jour. Nepal Geol. Soc., v. 25 (Sp. Issue), pp. 53-61.

Fujii, R., and Sakai, H., 2002. Paleoclimatic changes during last 2.5 Myr recorded in the Kathmandu Basin, central Nepal Himalaya. Jour. Asian Earth Sci., v. 20, pp. 255-266.

Gautam, P., Hosoi, A., Sakai, T., and Arita, K., 2001. Magnetostratigraphic evidence for the occurrence or preBrunhes (>780 kyr) sediments in the northwestern part of the Kathmandu valley, Nepal. Jour. Nepal Geol. Soc., v. 25, pp. 99-109.

Government of Nepal (GoN), 2009. Fourth national report to the conservation on biological diversity. Government of Nepal, Ministry of Forest and Soil Conservation, Kathmandu, Nepal, pp. $1-88$.

Gupta, H.P., and Sharma, C., 1986. Pollen flora of north-west Himalaya. Indian Association of Palynostratigraphers, Janki Bhawan, Narhi, Lucknow, India, 181 p.

Hesse, M., Halbritter, H., Zetter, R., Weber, M., Buchner, R., FroschRadivo, A., and Ulrich, S., 2009. Pollen terminology: an illustrated handbook. Springer-Verlag/Wien, $223 \mathrm{p}$.

Igarashi, Y., Yoshida, M., and Tabata, H., 1988. History of vegetation and climate in the Kathmandu valley. Proc. Indian Nat. Sci. Acad., v. 54A(4), pp. 550-563.

Khatri, D.B., 2015. Pliocene-Pleistocene climate reconstruction from the fluvio-lacustrine sediments based on plant megafossils in the Kathmandu valley, central Nepal. Master thesis submitted to the Central Department of Geology, Tribhuvan University, Kirtipur, Kathmandu, (Unpublished), 92 p.

Kral, F., and Havinga, A.J., 1979. Pollenanalyse und Radiocarbon datierung an Proben der oberen Teile der Sedimentserie des Kathmandu Sees und ihre vegetationsgeschichtliche Interpretation. Sitz. Ber. Öst. Akad. Wiss., math. Nat. Kl. Abt. I, v. 188(1-10), pp. 45-61.

Krutzsch, W., 1963. Atlas of middle and upper Tertiary dispersed spores and pollen as well as microplankton of northern middle Europe. v. 2, $421 \mathrm{p}$.

Malla, S.B., Shrestha, A.B., Rajbhandari, S.B., Shrestha, T.B., Adhikari, P.M. and Adhikari, S.R., 1976. Flora of Langtang and cross section vegetation survey (central zone). His Majesty's Government, Ministry of Forest and Soil Conservation, Department of Medicinal Plants, Kathmandu, Nepal. 269 p.

Malla, S.B., Rajbhandari, S.B., Shrestha, T.B., Adhikari, P.M., Adhikari, S.R., and Sakya, P.R., 1986. Flora of Kathmandu valley. Department of Medicinal Plants, Kathmandu, 962 p.

Mittre, V., and Sharma, C., 1984. Vegetation and climate during the last glaciation in the Kathmandu valley, Nepal. Pollen et spores, v. XXVI(1), pp. 69-94.

Mosbrugger, V. and Utescher, T., 1997. The coexistence approach a method for quantitative reconstruction of Tertiary terrestrial palaeocliamate data. Palaeogeography, Palaeoclimatology, Palaeoecology, v. 134, pp. 61-86.

Moribayashi, S., and Maruo, Y., 1980. Basement topography of the Kathmandu Valley, Nepal-An application of gravitational method to the survey of a tectonic basin in the Himalayas. Jour. Japan Soc. Engg. Geol., v. 21 (2), pp. 80-87.

Nakagawa, T., Yasuda, Y., and Tabata, H., 1996. Pollen morphology of Himalayan Pinus and Quercus and its importance in palynological studies in Himalayan area. Rev. Palaeobot. Palyno., v. 91, pp. 317-329.

Nemec, W., 1990. Aspects of sediment movement on steep delta slope. In: Cokella, A., and Prior, D.B., (Eds.), Coarse-grained deltas, Spec. Publ. Int. Assoc. sedimentol. v. 10, pp. 29-73.

Ooi, N., 2001. Last Glacial plant macrofossils discovered in the Kathmandu valley, Nepal. Japanese Jour. Hist. Bot., v. 10, 19 p.

Paudayal, K.N., and Ferguson, D.K., 2004. Pleistocene palynology of Nepal. 2004. Quat. Int., v. 117, pp. 69-79.

Paudayal, K.N., 2005. Late Pleistocene pollen assemblages from the Thimi Formation, Kathmandu valley, Nepal. The Island Arc, v. 14(4), pp. 328-337.

Paudayal, K.N., 2006. Late Pleistocene pollen assemblages from the Gokarna Formation, Kathmandu valley, Nepal. Jour. Nepal Geol. Soc., v. 33, pp. 33-38.

Paudayal, K.N., 2011a. Palynological assemblages from the Late Pleistocene sediments of the Patan Formation in Kathmandu valley and their climatic implications. Bull. Dept. Geol., Tribhuvan University, v. 14, pp. 59-66.

Paudayal, K.N., 2011b. High resolution palynostratigraphy and climate from the Late Quaternary Besigaon section belonging to Gokarna Formation in the Kathmandu valley. Jour. Strat. Asso. Nepal, v. 7, pp. 33-38.

Press, J.R., Shrestha, K.K., Sutton, D.A., 2000. Annotated checklist of flowering plants of Nepal. British Museum of Natural History, London, $430 \mathrm{p}$.

Punt, W., Blackmore, S., Nilson, S., and Le Thomas, A., 1994. Glossary of Pollen and Spore terminology. LPP Foundation, Utrecht, the Netherlands, $71 \mathrm{p}$.

Rao, M.R., Shani, A., Rana, R.S., and Verma, P., 2013. Palynostratigraphy and depositional environment of Vastan lignite mine (Early Eocene), Gujarat, western, India. Jour.. Earth Syst. Sci, v. 122(2), pp. 289-307.

Sakai, H., Fuji, R., Kuwahara, Y., Upreti, B.N., and Shrestha, S.D., 2001. Core drilling of the basin fill sediments in the Kathmandu valley for paleoclimatic study: preliminary results. Jour. Nepal Geol. Soc., v. 25, (Sp. Issue), pp. 9-18.

Sakai, T., Gajurel, A.P., Tabata, H., Ooi, N., Takagawa, T., Kitagawa, H., and Upreti, B.N., 2008. Revised lithostratigraphy of fluviolacustrine sediments comprising northern Kathmandu Basin in central Nepal. Jour. Nepal Geol. Soc., v. 37, pp. 25-44.

Tissot. C., Chikhi, H., and Nayar, T.S., 1994. Pollen of wet evergreen forest of the western Ghats, India. Institut Français de Pondichéry, $133 \mathrm{p}$.

Traverse, A., 1988. Palaeopalynology, Unwinhyman, Boston, 600 p. Yoshida, M., and Igarashi, Y., 1984. Neogene to Quaternary Lacustrine Sediments in the Kathmandu valley, Nepal. Jour. Nepal Geol. Soc., v. 4, (Sp. Issue), pp. 73-100.

Yoshida, M., and Gautam, P., 1988. Magnetostratigraphy of PliocenePleistocene lacustrine deposits in the Kathmandu valley, central Nepal. Proc. Indian Nat. Sci. Acad., v. 54A(30), pp. 410-417. 